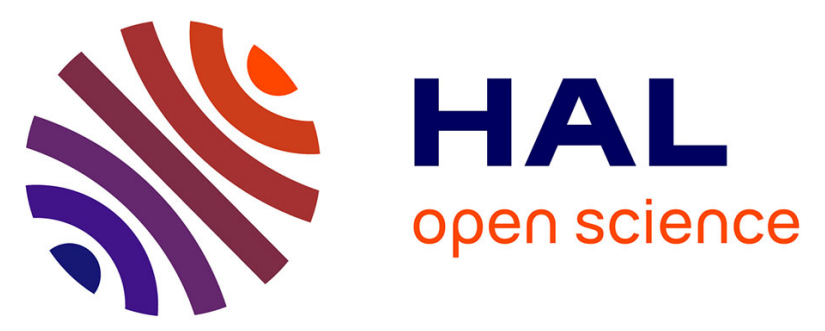

\title{
Exploring inter-firm knowledge through contractual governance: A case study of production contracts for faba-bean procurement in France
}

\author{
Célia Cholez, Marie-Benoît Magrini, Danielle Galliano
}

\section{To cite this version:}

Célia Cholez, Marie-Benoît Magrini, Danielle Galliano. Exploring inter-firm knowledge through contractual governance: A case study of production contracts for faba-bean procurement in France. Journal of Rural Studies, 2020, 73, pp.135-146. 10.1016/j.jrurstud.2019.10.040 . hal-02875100

\author{
HAL Id: hal-02875100 \\ https://hal.inrae.fr/hal-02875100
}

Submitted on 6 Apr 2021

HAL is a multi-disciplinary open access archive for the deposit and dissemination of scientific research documents, whether they are published or not. The documents may come from teaching and research institutions in France or abroad, or from public or private research centers.
L'archive ouverte pluridisciplinaire HAL, est destinée au dépôt et à la diffusion de documents scientifiques de niveau recherche, publiés ou non, émanant des établissements d'enseignement et de recherche français ou étrangers, des laboratoires publics ou privés.

\section{(1) (1) $\$$}

Distributed under a Creative Commons Attribution - NonCommercial - NoDerivatives $\mid 4.0$ 


\title{
Exploring inter-firm knowledge through contractual governance: a case study of production contracts for faba-bean procurement in France.
}

\author{
Preprint version
}

\author{
CHOLEZ Celia, MAGRINI Marie-Benoit, GALLIANO Danielle
}

UMR 1248 AGIR, INRA-Toulouse, Chemin de Borde Rouge, BP 52 627, 31326 Castanet Tolosan, France.

Corresponding emails: celia.cholez@live.fr, $\underline{\text { marie-benoit.magrini@inrae.fr }}$

Citation published version:

Cholez, C., Magrini, M.B. and Galliano, D., 2020. Exploring inter-firm knowledge through contractual governance: A case study of production contracts for faba-bean procurement in France. Journal of Rural Studies, 73, pp.135-146. https://doi.org/10.1016/j.jrurstud.2019.10.040

\begin{abstract}
:
A major sustainability challenge in European agriculture is to develop legume production. But organizing new legume supply-chains is a knowledge-intensive process, due to low past investment. In particular, technical knowledge development on crop production requires strong coordination between stakeholders. Even if contractual coordination in the agro-industrial sector is increasing, its role in inter-firm knowledge exchange is poorly understood. Drawing on qualitative case study, we explore how production contracts strengthened knowledge exchange between a processor and its grain-legume supplier's in France. Based on Transactioncost economics and the Relational-view of strategic management, this paper draws an original setting for practitioners and research to analyze contractualization from a learning perspective. The results show that collective contractual governance plays a major role for knowledge development through face-to-face interactions and specific intangible asset investments. This case study opens research agenda to analyze how contractualization brings the stakeholders into a collective progress curve.
\end{abstract}


Key Words: Supply chain, sustainable farming, transaction-cost economics, knowledge sharing, contractualization, agri-feed industry

\section{Introduction}

One main lever of sustainability transition in agricultural sector is higher crop diversification which requires the development of new value-chains for the minor crops (Bradshaw, 2004; Meynard et al., 2018). Developing new value chains requires a renewal of the stakeholder's knowledge base (Elzen et al. 2017; Ingram, 2017; Sumane et al., 2018) to overcome the lockin situation that prevails on minor crops compared to the major crops (e.g. Magrini et al., 2018). But if lock-in in agriculture is quite well illustrated (e.g., Cowan and Gunby, 1996; Vanloqueren and Baret, 2009; Magrini et al., 2016), it is unclear how to develop new knowledge for alternatives production practices.

If transitioning toward more sustainable practices depends on knowledge transfer trough research, extension and technical advice services (Labarthe and Laurent, 2013), it also calls for sharing one's experiences through collaborative strategies, as highlighted in agriculture and other manufacturing industries (Sumane et al., 2018; Carballo-Penela et al., 2018). Literature on sustainable supply chain management (SSCM) supports the idea that knowledge development is boundary-spanning (Gold et al., 2010; Kogg and Mont, 2012; Meehan and Bryde, 2011; Oelze et al., 2016; Pogutz and Win, 2016). Some studies show that interorganisational arrangements are more efficient in coordinating knowledge among productive stakeholders (Dyer and Singh, 1998; Mowery et al., 1996; Lam, 2005; Powell and Grodal, 2005) but the connection between those organisational arrangements (i.e. the chain governance structure) and knowledge dynamics is poorly understood (Nooteboom, 2004, Foss, 2007; Delmas and Toffel, 2008). 
Moreover, among the diversity of inter-organizational arrangements some studies suggest implicitly that contracts between a buyer and its suppliers could play a major role in context of changes (Albino and Berardi, 2012; Djanibekov et al., 2013; Gramzow et al., 2018; Melander, 2018). But while contracting for "propertizable" knowledge has been very much studied, notably for R\&D contracts or license contracts ${ }^{1}$ (Aghion and Tirole, 1994; Arora et al., 2004; Arena et al., 2012), there is a lack of evidence on how contracting for goods may also favor knowledge creation and transfer (Gobbato, 2013).

Thus, the objective of the study is to focus on the role of production contracts, whose main purpose is to frame the production and the exchange of a raw material (under mutually agreed specifications on prices, quality, and production conditions), and to explore how their governance structure fosters knowledge development between stakeholders, especially in the case of emerging alternative supply chains. That is, for chains whose knowledge needs to be developed to improve and stabilize the production engaged.

In this paper we use the term production contracts" to refers to the agreement between a buyer and its suppliers (either farmers or storage organizations) that frame the production and the transaction of a commodity (Bogetoft and Olesen, 2002). Thus, production contract is a form of "procurement contract" which term is often used in industrial sectors. The analysis of production contracts is linked to the phenomenon of "contract farming" which definition is given by Minot (2018: 127)): contract farming may be defined as agricultural production carried out

according to a pre-planting agreement in which the farmer commits to producing a given product in a given manner and the buyer commits to purchasing it." Contract farming is

\footnotetext{
${ }^{1}$ Those types of contracts- which are specifically designed for knowledge transfer or knowledge creation purposes- are beyond the scope of this study.
} 
strongly invested in developing countries, particularly as regards equity, farmer incomes, crop productivity and technological transfer (Bijman, 2008; Wang et al., 2014; Nguyen et al., 2015; Minot, 2018). Still, under the term of contract farming, there is a diversity of models (centralized model, outgrower model, multipartite model, informal model) that rely either on simple specifications contracts or on more complex contracts offering the full package of seed, agrochemicals, credit and extension (Eaton and Shepherd, 2001; Prowse, 2012) ${ }^{2}$. Here, we rather use the term "production contracts" as it refers more precisely to the type of agreement in itself and not to the more global phenomenon of agricultural production under contract. In western agriculture "productions contracts" between independent stakeholders have been studied by several authors, but little attention has been paid specifically to knowledge development issues. Indeed, the classical analysis of contracts remains the principal-agent perspective (Laffont and Martimort, 2002), examining how incentives (payment schemes and the length of contracts) affect farmers' efforts (Dubois and Vukina, 2009; Goodhue et al., 2010, Fares and Orozco, 2014). In this approach, contracts are a way to deal with asymmetric information while stating the contracting parties' abilities and preferences; but the knowledge dynamics surrounding the transaction is underestimated as pointed out by Brousseau and Glachant (2002).

To address these gaps and explore the complex links between contractual governance and interfirm knowledge, we present an exploratory case study of how a French feed-industry created a new crop supply chain to substitute one of its raw materials (imported soya from America) with a more environmental-friendly one (faba-bean) (Kopke and Nemecek, 2010; Dequiedt and Moran, 2015) but facing with a lack of knowledge on the way to cultivate it, as stressed by Zimmer et al. (2016) or Meynard et al. (2018). This lack of knowledge, both for the industry

\footnotetext{
${ }^{2}$ For an overview of works on contract farming, consult the FAO dedicated website on that subject : http://www.fao.org/in-action/contract-farming/
} 
and for farmers, creates uncertainty on the way to develop this production. To organize this supply chain with faba-bean, this company decided to design production contracts with several storage organizations, all gathered in an association.

Through this article we disentangle the mechanisms between this contractual governance and knowledge development in the emergence of a new supply chain. We begin by presenting the specificity of the study context, showing that developing faba-bean production in France (and more largely in Europe) is emblematic of a sustainability challenge as its production is hampered by a lock-in, resulting in a lack of technical knowledge on this minor crop (Zimmer et al., 2016; Magrini et al., 2016). Then we address our theoretical frame about contractual governance and inter-firm knowledge dynamics, by mobilizing Transaction Costs Economics (TCE) (Williamson, 1991) and the Relational-View of strategic management (RV). We thus show that efficiency of governance structure not only relies on economizing transaction costs but also on coordinating knowledge about the production process over time, thanks to knowledge sharing (Dyer and Singh, 1998; Langlois and Foss, 1999). After describing the method for data collection and analysis, we present the empirical results. In the last section we discuss how those results contribute to opens several avenues for research linking contractual governance and knowledge dynamics perspectives; and also offer original insights for practitioners to develop new chains when knowledge development is key for sustainability transition.

\section{Study context}

As underlined by a recent report from European Commission (2018), the development of plant proteins has long been a challenge for Europe, both to increase autonomy for feed -as EU feed sector is strongly dependent from imported soybean- and to develop new product for human food - as meat substitute is an increasing consumption tendency-. Among plant proteins crops, the European Commission presents legumes as the main crops to develop, both for their high 
protein contents and their specific agro-environmental benefits. Due to their ability to fix atmospheric nitrogen, legumes do not need for synthetic nitrogen fertilizers, meaning fewer GHGs emission (Kopke and Nemecek, 2010). Moreover, by diversifying crop systems, legumes enhance cultivated biodiversity and soil fertility (Magrini et al., 2018).

However, in Western countries, the incumbent agricultural system is still based on crop specialization on a few major species such as wheat and maize, enabled by the intensive use of synthetic inputs. Thus grain-legumes represent less than $4 \%$ of the cultivated area in Europe. This situation comes from path dependency mechanism favoring investment in major crops and far less in minor crops (Magrini et al. 2018). As an illustration, grain-legumes production is limited by the minor investments in plant varieties: more than 300 hundred certified varieties for wheat, but only 20 faba-bean varieties are registered in the Official European Union's Common Catalog of Plant Varieties Considering minor crops' lack of competitiveness, current direct subsidies do not provide enough incentives to increase legumes crops (Magrini et al., 2016).

Hence, practitioners, politicians and searchers agree that developing legumes production requires to go beyond direct producers incentives, by supporting structural changes at the level of the supply chain (European Commission, 2018). More precisely, developing new sustainable supply-chains for those crops must rely on "coupled innovations" between upstream and downstream stakeholders; involving both technical and organisational dimensions (Meynard et al., 2017). So, new business strategies on legumes should encompass new organisational arrangements between stakeholders but more empirical research is needed to support this statement.

To shape first propositions on which kind of organizational arrangements the legumes production can develop efficiently, our case study focus on a private volunteer procurement 
strategy implemented by a feed-industry Valorex to develop a new faba-bean supply chain, in Britany, in France. In the French feed sector, Valorex Company (founded in 1992) is a niche player whose growth strategy relies on product differentiation through technological innovation. Valorex uses whole oil and protein-rich grain-legumes with a patented thermoextrusion process offering better nutritional quality that, in turn, improves the quality of animal products in human food (Meynard et al., 2018). This premium quality comes with an extra-cost paid by consumers for those nutritional and environmental benefits. In 2014, the company decided to incorporate a new raw material: faba-bean, whose richness allows protein substitution for imported soya meals widely used in feed sector. Organizing this new supply chain reinforces the product differentiation of Valorex, by guaranteeing non-GMO feed and by marketing faba-bean positive environmental externalities.

As for Europe, faba-bean production is very scarce in France, accounting only for $2 \%$ of the cultivated area. French faba-bean farming amounts to about 300,000t annually (average 20112015) shared between: a major direct use by farmers for their own livestock (about 140,000t); some feed export outlets (about 35,000t in 2015) and some food exports which are rather unstable $(75,000 t, 2015)^{3}$. Hence, the faba-bean French processing feed market is very small and emergent one, for which no structured supply chain did exist before the Valorex initiative.

As growing this minor crop means changing usual farming practices, the success of the feedindustry procurement strategy depends on how stakeholders organize themselves to create, share and update the specialized knowledge available. The production contracts established by Valorex and its suppliers are likely to generate specific inter-firm knowledge exchange. To examine those processes, we present theoretical elements in the following section.

\footnotetext{
${ }^{3}$ Statistics come from the French grain-legume inter-profession Terres Univia.
} 


\section{Contractual governance and inter-firm knowledge: theoretical frame}

Given the global challenges of sustainability transition, creating new agro-industrial chains requires improving the knowledge base about alternatives production practices. Even if, contractualization on a product transaction can be tied to a technical support or advisory service for suppliers (Gobbato, 2013), this knowledge transfer may not be efficient in a transition context where new supply chain or new product are developed, as producers need to adapt "foreign" knowledge to their local settings (Sumane et al., 2018), their institutional background, or their organizational culture (Lam, 2005). Hence, knowledge creation and interfirm exchange may be required to support their own learning. This can occur either in a deliberate way or as a "by-product" of the production governance that will generate stakeholder's interactions. In particular, in the field crop sector, production contract are recognized as a privileged means for developing new crops as they reduce the transaction costs involved (Weleschuck and Kerr, 1995; Wilson and Dahl., 2014; Meynard et al., 2018). Contrary to traditional marketing contracts, which only specify delivery, quantity, and price conditions, crop production contracts are contracts that contain production specifications (both input and output specifications) (Ricome et al., 2016), which question the knowledge base of the stakeholders implementing them.

In this section we revisit the governance mechanisms advanced in Transaction Costs Economics (TCE) to show how contractual governance influences knowledge creation, especially through the lens of specific asset investment (3.1). Then, we extend this analytical framework by mobilizing the Relational View (RV) of strategic management (3.2) to analyze how production contracts could also influence knowledge exchange (3.3). 


\subsection{Contracts and knowledge creation: insights from the TCE}

Transaction Cost Economics focuses on governance structures choice according to transaction characteristics, especially their level of uncertainty and assets specificity. ${ }^{4}$ First, high level of uncertainty justifies to go for more coordinated organizational forms, as hybrid forms or integration, either than spot markets (Williamson, 1991). This question of knowledge uncertainty has been particularly investigated through the measurement branch of TCE (Barzel, 1982; Mazé, 2002). Second, other studies question the specificity of investment that cannot be re-used (in another transaction) without generating additional costs (Williamson, 1989). As stakeholders may behave opportunistically, the asset specificity increase exchange hazards like ex-ante problem of under-investment or ex-post hold-up. Asset specificity often concerns technologies as well as human specificity (Anderson and Schmittlein, 1984). Even though a coordination of decisions and pooling resources to develop specificity assets may be needed, keeping a certain level of autonomy among stakeholders remains important when each of them has particular competences: for instance if technological complementarity is strong in a supply chain or if stakeholders want to make systemic innovation (Ménard, 2012). That is the reason why hybrid forms can be preferred to integration. But, this high interdependency among stakeholders calls for efficient contractual safeguards allowing enforcement through public or private ordering (Williamson, 1989, Mazé and Ménard, 2010). And if formalization of a contract is a way to encourage actors to give up opportunistic behavior, informal arrangements are also used to favor cooperation over time through mutual learning (Mazé, 2002, Raynaud et al., 2009; Ménard and Valceschini, 2005). Indeed, as stakeholders have "bounded rationality", contracts are necessary incomplete and appeals for other devices that allow adaptation.

\footnotetext{
${ }^{4}$ In our study, the frequency of the transaction is not taken in account as its role is very controversial in the TCE literature (Williamson, 1989; Baker et al., 2002), but we focus on the nature and the frequency of the face-toface interactions occurring through the contractual governance and by which knowledge exchange occur (see section 3.2).
} 
This classical trade-off between contract formalization and governance flexibility matters a lot in agriculture, where uncertainty surrounding crop practices and market conditions, combined with uncertainty about nature (climate, pests) often hampers the design of formal contracts (Allen and Lueck, 2000; Watanabe et al., 2017). It also concurs with transition studies in agriculture which consider the trade-off between efficiency and adaptability of production systems, as a crucial factor for change (Darnhofer et al., 2010).

Thus, hybrid forms combining contracts and other organisational arrangements are considered as "efficient in dealing with knowledge-based activities, solving hold-up problems, and reducing contractual hazards” Ménard (2012: 1066). Here, efficiency means economizing on transaction costs. In addition, these hybrid forms help production planning and creating value collectively by coordinating knowledge about the production process over time (Langlois and Foss, 1999, Mazé, 2002).

To go further on the knowledge exchange that could occur through this contractual governance of hybrid forms, we mobilize the "relational view" of SM.

\subsection{Inter-firm knowledge exchange: insights from the Relational-view of SM}

According to the Resource-based view and the Knowledge-based approach, the firm generates its competitive advantage thanks to its unique set of resources and capabilities (Penrose, 1959; Grant, 1996). But, work on interfirm collaboration highlights the mutual benefits of interorganizational knowledge transfer (Nickerson and Zenger, 2004; Powell and Grodal, 2005). Thus, the Relational-View (which is an extension of the previous approaches) stresses the fact that value creation can be boundary-spanning, which is particularly important when addressing buyer-suppliers relationships in a value-chain under development (Gold et al., 2010; Brennan and Tennant, 2018). From this perspective, knowledge exchange between firms, and the combination of their complementarity resources, allow for "joint learning" and "joint creation of unique new products, services of technologies" (Dyer and Singh, 1998). This view 
emphasizes the role of knowledge-sharing routines, defined as "a regular pattern of interfirm interactions that permits the transfer, recombination or creation of specialized knowledge" (Grant, 1996).

Especially, codified knowledge, like know-what, i.e. knowing facts can be easily transferred trough "information-sharing" routines, for instance using database (Jensen et al., 2016). On the contrary, know-how, which refers to skills and actors' abilities, is more challenging to exchange, because it is "sticky" and tacit, i.e. difficult to explain and document (Cowan et al., 2000). Tacit knowledge transfer will require frequent sociotechnical "face-to-face interactions"(Dyer and Singh, 1998). As underlined by Aydogan and Lyon (2004): "Visits to the facilities of other firms become important when knowledge is tacit, since a firm's representative can only communicate his tacit knowledge effectively on the premises of his own firm. Thus, successful knowledge exchange requires that both firms travel to one another". Hence, the frequency of relations and exchanges determine another characteristic of the contractual governance in addition to the frequency of the transactions on the good exchanged. The frequency of those interactions might increase the trust between parties and thus favor, on the one hand, the reduction of opportunistic behavior, and on the other hand, the increase of knowledge exchanges (Sharfman et al., 2009). Still, several issues arise in inter-firm knowledge dynamics, such as the participants' motivations and agreement on common goals (North, 2005; Mazé, 2017), the cognitive distance between them, their absorptive capacity (Cohen and Levinthal, 1990) or knowledge spill-over risks (Nooteboom, 2004). Regarding the latter, some authors argue that knowledge transfer requires long-term contracts with specific provisions - such as restrictions on the use of the knowledge transfer - while others emphasize the role of trust (Nooteboom, 2004; Gobbato, 2013). Finally, even though the RV address governance issues as regard transaction costs and value-creation, it often highlighted the role of informal self-enforcement agreement, undermined the role of contractual governance in inter-firm knowledge exchange. 


\subsection{Inter-firm knowledge exchange trough contractual governance: toward a new analytical framework}

Several strategic management studies recognize contract as a repository of knowledge (Mayer and Argyres, 2004, Reuer and Arino, 2007; Li et al., 2010), allowing for codified knowledge transfer through its technical specifications. Moreover, through the whole governance structure, contracts can support learning-by-interaction leading to a form of inter-organizational learning (Mazé, 2002; Nooteboom, 2004; Lam, 2005; Mazé, 2016). Thus, contracts may "provide the ground for disclosure and exchange of additional information and knowledge beyond what is described in the contract" (Leone, 2016)

In addition, literature distinguishes two types of learning: the "Science, Technology, Innovation » mode (STI) and the « Doing, Using, Interacting » (DUI) (Jensen et al., 2016). The STI mode relies on learning off-line through internal R\&D activities and access to external codified knowledge. Instead the DUI mode relies on learning on-line during the production process, also known as learning by doing (Arrow, 1971). For instance, in agricultural sector, some studies emphasize the role of extension services' back-office, to create technical references that can either lock-in or unlock the current production system (Labarthe and Laurent, 2013) (ie. learning off line); whereas other studies highlight farmers' experiential learning (ie. learning by doing) in developing new crop knowledge adapted to the local context (Darnhofer et al., 2010; Caron et al., 2014). ${ }^{5}$

Based on those previous settings, one can ask what would be the effect of contractual governance on interfirm knowledge creation or exchange; and how those different types of learning occur, as visualized in figure 1? Which organizational conditions could be an efficient way to engage stakeholders of a supply chain in developing collective knowledge?

\footnotetext{
${ }^{5}$ Distinctions are useful for analytical purposes, but these two types of knowledge creation may converge, with feedback mechanisms between them (Arena et al., 2012)
} 
[Figure 1]

To address empirically those questions, we conduct an in-depth case study detailed hereafter.

\section{Method}

To explore how governance through production contract may serve interfirm knowledge development, we draw on an in-depth case-study of how a feed producer in France -Valorex-, organizes a new value chain based on faba-bean. Several reasons justify this method. As Yin (2014) stated "the need to use a case study arises whenever an empirical inquiry must examine a contemporary phenomenon in its real-life context, especially when the boundaries between phenomenon and context are not clearly evident." Moreover, as highlighted in the contract literature, there is little empirical data on contracts in agriculture (Sykuta and James, 2004). For instance, in France, there is no database of agriculture contracts as they remain private. Furthermore, the purpose of this study is not to statistically verify the correlations between existing contracts and knowledge; but to disentangle the complex process of how contracts may be linked to knowledge creation and exchange. This line of questioning lends itself particularly well to an in-depth case-study method.

\subsection{Data collection}

The faba-bean procurement strategy initiated by Valorex combines:

(i) bilateral production contracts with farmer organizations being the faba-bean suppliers

(ii) collective contractual governance through a non-profit association, Graines Tradition Ouest (GTO) which gathers the farmer organizations supplying faba-bean

In that way, Valorex production contracts rely on a network of historical suppliers grouped into the GTO association which goal is "the organization of production, supply, and sales to processing companies of oilseeds and pulses among the economic partners involved." (as mentioned in its status rules). GTO is the extension of an older association created in 2002 to 
develop a linseed supply chain, whose status has evolved since 2014 to encompass the development of faba-bean supply chain. GTO is made up of faba-bean suppliers, a seed company, and a person in charge of administration. Suppliers in the GTO association include five competing storage organizations (SOs) (among which four are cooperatives and one is a private business); as well as two independent farmers (FSOs) that have their own storage capacity and were historical suppliers of Valorex. In the case of storage organizations, each one will sign corresponding production contracts with farmers (Fs) belonging to it. The farmers are either clients (for private storage organizations) or members (for cooperatives) but there is no differences in the way those productions contracts are designed. The frame of the production contracts is the same for every organization (except some minor difference concerning the incentives mechanisms and more precisely the time for payment, which can be fractioned or not, according to firm strategy).These organizations have different marketing strategies, but they are all looking for (i) crop diversification to move towards more sustainable systems and (ii) strategies for creating new added value to improve farmers' incomes. For them, a new contracted outlet for faba-bean is an interesting opportunity. In 2015, 2,000t of faba-beans were under contract with Valorex. For these organizations, the 2014-2015 faba-bean campaign accounted for 0.01 to $0.3 \%$ of their total harvest crops, while wheat accounted for $49 \%$ to $72 \%$. Indeed, in this region, traditional crop systems are composed essentially of wheat, maize, barley and colza. Appendix A details the characteristics of each organization. Figures 2a summarizes the collective governance of bilateral production contracts through the association GTO and figure $2 \mathrm{~b}$ specifies the commercial links between those stakeholders.

[Figure 2a]

[Figure 2b] 
Our investigation is based on 14 semi-structured interviews ${ }^{6}$ for 2 to 3 hours with at least one representative from each member of the GTO association. These included the administrator of the association (from an extension service), the seed company, all the suppliers with whom Valorex had established production contracts in the last two years, and the Valorex employees involved in purchasing and more generally in building the faba-bean supply chain. The small$\mathrm{N}$ study remains appropriate regarding the representativeness of all the organizations involved in the contractual governance (Baker and Edward, 2012). The interview grid was designed following the previously mentioned analytical framework; and used for all the interviews allowing for triangulation of the information (Yin, 2014). Main items addressed during the interviews, and characteristics of those interviewed, are summarized in Appendix B.

\subsection{Data analysis}

All interviews were then transcribed to identify the excerpts of direct speech that would enable us to investigate our research question. The dimensions of contractual governance and knowledge were coded iteratively through each transcribed interview, to identify the mechanisms that linked the two dimensions (Saldana, 2015). Narratives were also selected when they were illustrative of a particular mechanism. The narratives used in this article were anonymized, and we use a code for each quote (Appendix B). We also complemented the data corpus by analyzing professional documents (status of the association, the GTO production contracts, sales brochures) and by participant observation by one of the researchers for one month at Valorex.

\section{Study case findings}

Firstly, this section shows the need for inter-firm knowledge creation in the faba-bean supplychain and examines the collective contractual governance implemented according to TCE

\footnotetext{
${ }^{6}$ It is part of a larger research project on grain-legume procurement in France involving more than 100 semistructured interviews with farmers (Mawois et al., 2017) and others semi-structured interviews with institutional stakeholders (Magrini et al., 2018)
} 
considerations (Part 5.1). Secondly, we analyze more precisely how those contractual governance mechanisms foster knowledge exchange, and thus, inter-firm learning (Part 5.2).

\subsection{The need for inter-firm specific knowledge and the contractual governance implemented.}

\subsubsection{The need for new knowledge on faba-bean production.}

Faba-bean transactions are marked by great production uncertainty resulting from a lack of knowledge on farming practices adapted to the local context, as mentioned in all interviews. Stabilizing yields was notably highlighted as a priority by the seed company. While the uncertainty about yields depends on natural resources (soil and climate conditions, genetic material available), respondents also stated that there is uncertainty about farmers' growing practices because of a lack of expertise. Introducing faba-bean crop in a new area involved uncertainty about how to grow it (know-how):

One limiting factor is to try to grow a new crop and not mess it up...there is the unknown; it's jumping feet first into a crop that we don't know at all. (SO3)

In areas where it's not done [grow faba-beans], they're afraid to do it! Because historically, they have done tests and the results weren't satisfactory. If we had to grow faba-beans throughout all of Brittany on a large scale, well, that'd be a lot of work! (SO5)

It's not the same as doing wheat for export! Wheat export, everyone knows how to do that! (SO4)

Hence, storage organizations had to deal with farmers' lack of knowledge about growing this crop. But this lack of know-how also directly affected the storage organizations, especially the farming advisors who work for them:

None of us is a specialist in this crop.(SO1)

What is needed is a technical reference person....This could be a member [of the association] but today no one is an expert... I think that today we don't have the experience and the skills [to grow this crop]. (SO5) 
This uncertainty about farming practices was primarily related to managing crop pests (weevils), diseases and weeds, and to controlling crop height.

In addition, creating a market outlet for a new product also means defining the nature and quality of the good sold and how to reach it. Upstream actors must acquire knowledge about the qualities of the beans, particularly protein levels and anti-nutritional factors (know-what); and knowledge on how to produce these qualities (know-how), that is to say, the feasibility or acceptability of the buyer's requirements or expectations:

For me, Valorex must decide, because it's Valorex which is the end point. So those people, they have specific expectations. We must try to meet as best as possible their expectations. After that, to know how to meet their expectations, etc., well that's another debate! (SO3)

After, it's the knowledge of the various qualities and for that, you have to have a bit of experience to set it up. Here, we're just starting and so we don't know what the processing industry's needs in terms of quality. Does the technology used enable us to avoid vicines and convicines? We actually don't know! (SO2)

And we still don't know what they want exactly in protein...I'm not at all sure that the quality delivered is what they will want in five years, today we're growing as best we can... (ES)

For Valorex, the goal is that the protein content is the highest possible; after that, there may be an incentive grid, but behind that, can the farmer's practices actually improve things? I don't know! (SO5)

If Valorex tells me they want faba-beans with this or that characteristic, which can be easily identified, and that depends on such and such growing methods, and that the farmer can have an impact all that... then you can set up quality specifications, but otherwise we cannot implement a quality grid when we cannot act in such a way as to achieve it! (SO1)

Creating a faba-bean chain meant that the actors were able, on the one hand, to coordinate in a context of uncertainty and, on the other hand, to improve at the same time the stakeholder's knowledge base about crop production and farming practices. Afterward, we analysis how 
contractualization allows for specific investments, that improve stakeholders know-how and know-what.

\subsubsection{The contractual governance chosen: flexibility and cooperation among competitors to develop inter-firm specific knowledge.}

The combination of formal bilateral contracts and more informal collective governance in the association GTO ensured flexibility and a long-run cooperation between competitors. As the contracts only partially specified the mutual commitments between each member and the feed company, the association GTO serves as a specific governance entity to collectively frame the faba-bean exchanges, by regulating the production at the scale of the company's supply region. The table 1 summarizes this governance structure.

\section{[Table1]}

In this case, the governance of faba-bean transactions is a hybrid form, with partners sharing some decision rights, while keeping assets and property rights distinct. It is a hybrid form between the market and hierarchy, because it implies authority by agreeing on production conditions (with a high tolerance limit), while maintaining price incentives.

The peculiarity of this form of organization is to bring together competing organizations around a common goal: developing a sustainable supply chain for a new crop. Members thus pool resources (annual membership, development strategy, and working time) in order to structure this chain while remaining competitors:

There's a good atmosphere in the association, even though in reality we are competitors. I mean, people work smart, you know. For now everything's going well. (SO5)

I think we're all learning. We learn to live together as competitors, I mean, working together. Because in fact, we are competitors but we work together! There's some friction every day ... that happens, but at some point we [see] that we also have things in common which enables 
us to work together in one region...Competing companies can also work together! (SO4)

It's not common to have several operators like that on a project. Well, it's also because it's a small project, you know. I think it'd be more complicated if we managed wheat ... Then again, it's always the same, if we do it, it's really in specific niches. We couldn't do this with more standard products...(SO5)

Membership in the association and thus access to production contracts was subject to a selection process, which is based on the geographical complementarity of the suppliers' collection area. The history of the relationship and reputation also played an informal role in the selection process:

[Membership in certain storage organizations was denied] because originally they had not been interested and they only came [later] because they saw an opportunity, and there is nothing worse in a supply chain than people who come because it's a [business] opportunity, [because] at some point, the whole thing falls apart. (SO4)

Uncertainty about opportunistic behavior among GTO members was never highlighted by the actors interviewed. This could be because a relationship of trust had been built between the members of GTO, which had been created to develop linseed more than ten years ago. Bringing several competitors together also act as a form of informal peer monitoring.

The production contract between the company and its suppliers includes a commitment to purchase/sell faba-beans; that is signed before sowing the crop, with delivery obligation starting from the harvest until 4 months. Its duration is limited to one growing season and is renewed tacitly for each crop campaign.

So, contract remains short-term and rather incomplete. Agreement on price, quantity and quality is not the topic of the present paper, but we can just mention that stakeholders have to deal with 
high yield uncertainty ${ }^{7}$ and high market uncertainty ${ }^{8}$. The rationale behind minimum price fixation is that it ensures the farmer a margin equivalent to major crop like maize or wheat (around $500 € /$ ha). As no references are readily usable in the growing conditions in Brittany, evaluation of production costs and yield was still under debate during the negotiations to determine this margin.

During the growing season, the members met three to four times during "board meetings" to negotiate, enter into, monitor, and adjust the framework production contract to events that could affect production volume or quality (seed availability problems, climate conditions, etc.) or the market (an extra price can be negotiated after the harvest according to soybean market variation). At the supply-chain is just emerging, better assessment of price margin and grain quality thus requires investing in knowledge development.

\subsubsection{Investments for inter-firm specific knowledge}

We saw that Valorex gives members more visibility about market outlets by defining contractualised volume, and a fixed price, which would guarantee a margin at least equivalent to that of a major crop. Thus production contracts act as an incentive to invest. As the contract duration is short-term (1 year), joining an association and the perspective of a quasi-rent through value creation is complementary to encourage investment. When the contracts were set up two years ago, all the SOs who are GTO members committed individually (to setting up training programs or support for their farming advisors) in order to improve farmers' know-how.

We started to train advisors, so they're ready to go to train farmers! (SO4)

\footnotetext{
${ }^{7}$ Based on the storage organizations declarations, the range of yield variability is "higher to much higher "than on major crop: between 2.5 and $7 \mathrm{t}$ per ha. The storage organizations' perception of yield uncertainty is consistent with the agronomic literature showing that these crops do have more variability in yield than major crops such as cereals (Cerney et al., 2015).

${ }^{8}$ While some indicators of market price can be provided by brokers, there are no quotes for faba-beans on the futures market
} 
It's a course for two or three days, where we present the latest developments ... and then they (advisors) are given a book that allows them to monitor the crop and have an answer for anything that they may find problematic. (SO2)

The farming advisors are multi-talented... however, when they have a question about grain-legumes they'll call the engineer responsible for them. (SO2)

At our place... I trained them (laughs!) It's a crop I know, so I trained them and go around with them to see things [in the field] and so when they have a problem, they call me. (SO3)

These actions drew on resources and expertise available internally, which were limited for the majority of GTO's members, as we have seen. One challenge, therefore, was to encourage investment in acquiring new knowledge. The knowledge acquisition concerned both the suppliers and the buyer who need to invest deliberately in their own individual R\&D activities (on seed variety, agronomic practices, environmental benefits of the crops, grain transformation process, etc.). The seed company is also directly involved as in France, in 2015 only two companies conduct significant plant breeding program on faba-bean. The feed company is currently researching faba-bean qualities, especially protein digestibility, amino-acid and fatty acid composition, and anti-nutritional compounds, depending on the technological process (thermic, mechanical, or enzymatic) in a five-year R\&D program. From the supplier's point of view, investment in such knowledge development was a dedicated asset, since here the market structure was a monopsone. From the buyer's point of view, investment in knowledge on fababean growing was partly specific to these suppliers since research on quality parameters is partly depending on the farms' location. Hence a geographical specificity exists.

While the largest organizations in the group already invest for R\&D activities, it is doubtful that the smaller ones would be able to do the same. Thus, pooling resources in order to collectively invest in training or experimentation is an alternative to reach scale economies that the stakeholders envisaged, but which is challenging as a good deal of disparity remained among members, along with mid-term uncertainty: 
We also have to improve or perfect our skills on monitoring this crop, but here again, it's always a question of scale, because currently we're very limited and we're not going to deploy the heavy artillery [put great effort] on something that's small for now. But if this ends up growing, then yes, I think there's a need [to invest to improve]. (SO1)

Thus, the governance structure allows for flexibility and adaptation, also letting space for future improvement through knowledge development. The next section analyzes how this contractual governance generates inter-firm learning that is need for crop production, thanks to knowledge exchange.

\subsection{Contractual governance and inter-firm learning effects}

\subsubsection{Inter-firm knowledge exchange through contractual governance}

While individual and collective investment for knowledge is needed, contracts and their governance structure appear as main support for interactions and collective learning.

First, the production contract favors exchange of codified knowledge. Writing up a contract, whose terms are discussed in the meetings, allowed for the exchange of codified knowledge about plant varieties and crop management. For example, the list of varieties encouraged the SOs to use ones with a solid base of reference information (assembled by the seed supplier or by the SOs which also produce seeds) and which fit well with the buyer's needs.

Moreover, while the production contract imposed no requirements about the farming techniques to be used, one of the contract obligations was to fill out a form on crop management for Valorex. This sheet listed all the practices done during the growing campaign as reported by the grower. After the harvest, the form was sent to Valorex. This bottom-up information transfer, when aggregated together, constitutes a base of information about the practices of the farmers supplying the storage organizations ${ }^{9}$. As of now, data gathering and analysis was done by the feed producer/buyer, since it initiated the project and wanted to address the correlations

\footnotetext{
${ }^{9}$ Some unusual finding is that attribution of property rights on the collected date were not discussed within the association studied, and there was no clause dealing with that issue in the bilateral contract. Yet, it is true that the buyer's appropriation of individual farmer's data may be a stumbling block for the association at mid-term.
} 
between farming practices and grain quality (quantity and quality), in order to increase the common knowledge base and improve suppliers know how and know why.

Every year, there is someone doing a work placement at Valorex who analyses the crop management forms to work on progress. We did this with linseeds, and we're starting to do it with faba-beans. And for each plot of land, qualitative analyses are done. (SO3)

The storage organizations fill out a post-collection form for each parcel so that the farmers identify everything that was done, and yield performance, and eventually analyze in terms of practices what worked and what didn't. We're working towards a qualitative analysis (I)

Secondly, we uncover two main ways in which contractualization generates tacit knowledge exchange through face-to-face interactions: (i) during the contract negotiations and procedures for adapting them (three or four times a year); (ii) during meetings at the farmers' or SOs' fields or at Valorex (the buyer) premises ${ }^{10}$ (once a year). During negotiations, exchange is only between storage organization managers and the buyer. The knowledge exchanged concerns principally final product requirements and technical obstacles to reach them (such as yield and protein content variability of the collect, lack of references on variety behavior, difficulty of certified seed procurement, or lack of technical advisors in the organization), that is to say, mainly know-what. During field events, farmers and technical advisors are also involved. Exchange concerns much more pragmatic knowledge on production practices, that is to say know how embodied in a given situation: how to adjust the sowing machines (which are either cereal sowing machines or mono-grain sowing machines used for corn, as faba-bean grains are bigger than other cereals), how to manage weeds, how to manage pests, and how to avoid split grain during the harvest.

When there is an event, we're all there. Last year, it was a concurrent cooperative who organized it ... we were all present, that is to say, that

\footnotetext{
10 Thus, these discussions involved farmers or technical advisors that are engaged in production under contracts but did not necessarily take part in collective negotiation meetings, previously mentioned.
} 
we brought our farmers, our farming advisors, and everyone got involved. But you know, it doesn't draw massive crowds either, eh...When there are 50 growers there, we're happy. (SO1)

Beyond the economic aspect, we exchange, we progress together, we coexist more easily, that create exchanges between the storage organizations and between farmers and I think it's good...And as I told you, at the GTO field meeting, we'll go to a farmer's land who's a member of one of the competitor storage organizations, and we don't feel uncomfortable...It's these things that create a kind of clever emulation of each other, while remaining competitors, that makes the whole system progress... (SO4)

There is the sharing of experiences, too. It's true that it's always interesting because we don't all work the same way. This helps to see how the other organizations work; it's always interesting to talk with others in the same business. (SO4)

This brings together companies that are also competitors, and at least on this issue we can share with other partners who work in the same industry and we also share the same goal of development [i.e. faba-bean growth]. (SO5)

The Table 2 sum-ups the different mechanisms involved in knowledge acquisition and transfer through contractualization.

[Table2]

\subsubsection{Contract as a support of learning off-line and on-line:}

Finally, the mechanisms by which contract and knowledge are linked can sustain two types of learning: "off-line" and "on-line".

First, consistent with TCE prediction, as specific knowledge acquisition is required, it creates a mutual interdependency that justifies contractual arrangements more coordinated than market. Thus, by protecting asset specificity and limiting the role of hold-up problem thank to an association, the contractual governance allows for learning off-line to take place. By off-line, we mean investment in a traditional R\&D activities or technical advisors training. Developing suppliers and industry own private expertise trough learning off-line is a necessary step, because the stakeholders need knowledge adapted to the local growing context in Brittany, and the 
specific requirement from the feed industry (that aims at creating value through differentiation strategy). Because of that specificity, the buyer could not simply pay to bring in consultants from outside to train the suppliers. ${ }^{11}$

Then, the second finding is that production contracts can sustain a form of collective "on-line learning". On-line learning refers to the idea of developing knowledge during the production process in itself (also known as DUI learning). Using production contracts allows for knowledge capitalization through monitoring procedure. Indeed, by introducing clauses in the contract requiring the collection of growers' data on their production practices, the buyer obtained access to codified local knowledge. Collective analysis and restitution can then engage suppliers in a progress curve, and leads to better contract formalization. Then, contractual governance is implemented through meeting events, where stakeholders had to travel to the others' places. Those face-to face interactions favors tacit knowledge exchange. In those case, learning-by-interaction is deliberate (e.g. exchanging technical knowledge is the main purpose of field event) but also a by-product of contract implementation (e.g. negotiation reveals stakeholders knowledge even if it is not always the first purpose).

\section{Discussion}

Several lessons can be drawn about the mechanisms under which contractualization for goods foster knowledge development. Those contributions are twofold: on the one hand, those insights can help practitioners that want to develop new supply chains; on the other hand, those lessons have theoretical implications opening new research agenda.

On the whole, this study shows that reducing transaction costs and enhancing knowledge through contracts are two sides of the same coin. This departs from traditional literature on

\footnotetext{
${ }^{11}$ While experts for faba-bean production might be found in countries such as Italy or Germany, which are the main European producers of grain-legume, the varieties used there and crops systems are not the same as in Brittany, notably because in those countries faba-beans have historically been cultivated for human consumption, not for feed.
} 
production contracts and contributes to a better understanding of the contracts in practices, which is crucial to build bridges between searchers and practitioners (Bogetoft and Olesen 2002).While contracts help organize transactions and secure specific assets, the way those contracts are implemented also generate face-to-face interactions between stakeholders, which ended up fostering knowledge exchange. Bringing together several suppliers into an association would at first seem surprising because it reduces the buyer's bargaining power, as shown in other work on contract farming (Bogetoft and Olesen, 2002). On the other hand, this collective contractual governance helps to reduce the buyer's transaction costs by pooling the stages of negotiating and contract monitoring. Above all, contract can have a transformative role in supply chain; by bringing actors together into a community that develop new common knowledge, for changing production practices. This empirical research thus support the theoretical statement that contracts is not only a way to reduce transaction costs, but also a means to create value by coordinating knowledge about the production process over time (Langlois and Foss, 1999; Ménard, 2012). This case thus highlight that contractualization can brings the stakeholders into a collective progress curve, supporting continuous improvement. This has a theoretical implication regarding TCE analytical framework and leads to the following proposition:

Proposition1. Discriminating alignment hypothesis between governance structure and transactions should pay more attention to maximizing value through inter-organizational arrangements on the medium term, and not only on economizing transaction costs at the short term.

Moreover, it also contributes to sustainable supply chain management literature (SSCM). Our finding concerns situations in which stakeholders want to create new products, source new raw materials or start new activities, for which lack of knowledge leads to uncertainty and for which local adaptation is needed. Sustainability transition in agriculture is very much concerned as 
local environmental conditions, natural resources and practices matters a lot. But it is a more generalized problem in value-chain organization as soon as local knowledge empowerment is needed for developing green product or processes (Gold et al., 2010; Sarkis et al., 2011). Contract thus appears as an interfirm process among which immaterial resources can span boundaries and create competitive advantage (Dyer and Singh, 1998; Duschek, 2004). As literature on SSCM often focus on logistics or managerial dimension, we highlight the importance of designing adequate organizational arrangements between stakeholders, according to the type of knowledge issues they encounter. When knowledge and skills exist outside the supply chain, tying bilateral contracts to the technical advising provided by an external consultant may be a solution (Arora et al., 2004; Wang et al., 2014). Nevertheless, many studies have shown the limits of this top-down transfer approach when dealing with new environmentally friendly products or activities, which are associated with new specific knowhow (Van Hoof and Lyon, 2013). In those cases, contractualization should be implemented in order to foster learning on know-how and know-what. This implies to combine vertical dyadic production contracts with collective governance structure favoring interactions, which departs partially from the collaborative SSCM studies focusing on informal link (Scharfman et al., 2009; Carballo et al., 2018). This leads to the following proposition:

Proposition2. The complementarity between vertical production contracts and collective governance structure, between a buyer and its suppliers, foster learning by interacting, necessary to sustainable supply-chains development.

Hence, the two propositions we mentioned might guide future research design and data collection in order to address more systematically (i) specific immaterial assets investment and protection (ii) face-to-face interactions devices linked with contract implementation (iii) level of learning between stakeholders (iv) both transaction costs and value creation; particularly in transition contexts requiring a new knowledge base shared between actors, such as in organizing 
new supply chains. By addressing face-to-face interactions, our study highlights the importance of the frequency of exchanges between the stakeholders. Thus, it contributes to the literature on frequency, by extending previous work (e.g. Baker et al., 2002) and by showing that it is not only the transactions repetition that generates learning but also the frequency of interactions during the contractualization process in itself.

\section{Conclusion}

This paper presents an exploratory analysis of the complex mechanisms linking contractualization and knowledge development when uncertainty is at stake in an emerging supply-chain. We address how a buyer substitutes part of its raw material with another one more environmental-friendly, and overcomes the lack of knowledge on this alternative supply chain through specific contractual governance. This paper provides a business case "success story" that inform practitioners about empowering private knowledge and contractual governance, between buyer and suppliers, when renewal of their knowledge base is required.

If our findings support the alignment principle of Transaction Cost Economics, claiming that contractual governance is chosen by stakeholders that want to develop idiosyncratic relationship based on knowledge specificity; our study more specifically highlights how the complementarity of vertical bilateral contracts and collective contractual governance (here through an association) foster knowledge development through learning by interaction process.

This single case-study is a first-step in understanding those mechanisms. Hence, further study cases have to be conducted in order to deepen the particular conditions under which contractual governance increase knowledge creation and exchange. Extending our approach to others sectorial and national contexts will allow meta-analysis. This will also allow studying the 
impact of institutional environment on contractual and organizational capabilities development among private stakeholders.

Our study presents some limitations and further research could also go deeper in a future research agenda.

Firstly, the conclusions we gave regarding organizational learning dynamics focus on the emergence stage of a supply chain. A better assessment of the forms effectiveness over the longer term would require a longitudinal case study with contracts established for several years. That is to say, to specify how relationships and trust among participants evolve over time through the repetition of contracts.

Secondly, concerns on data appropriation rise specific issues in the contractual and knowledge dynamics. As private individual data, gathered through those contracts, represents a source of collective added value, the way actors define property rights allocation should be clarified in order to sustain continued knowledge exchange between members (Arena et al., 2012); and so, analyzing the way actors design those property rights is of interest.

Thirdly, our study reveals stumbling points regarding the level of farmers' inclusiveness of contractual and organizational strategies. The contractual governance we studied is restricted to a niche market based on a monopsony that questions the level of inclusivity. The scope of knowledge diffusion outside the involved stakeholders remains a critical aspect in transition studies toward more sustainability (Labarthe and Laurent, 2013). Additional research on the internal organization characteristics of each $\mathrm{SO}$ and the criteria they used for farmers selection would help us to understand better those processes. Even if, farmers implication in governance was not the focus of this paper, one result of our case study is that farmers do not take part in the contract negotiations, neither in cooperative, nor on private storage organizations; and that there is no difference between production contracts implementation by cooperatives or private 
storage organizations. This result is opposite to previous results in the literature (e.g. James and Sykuta, 2006) that show strong differences between private storage or cooperatives, due to differences in trust and governance rules. We could explain our result by the recent changes in relationships between farmers and their cooperatives due to the growth of cooperatives structures (Barraud-Didier et al., 2014). Still, future research will be needed to test this hypothesis and examine more closely farmers' individual characteristics in accepting contracts links, as well as the storage organizations characteristics in proposing those contracts.

\section{References}

Aghion, P. and Tirole, J., 1994. The management of innovation. The Quaterly Journal of Economics 109(4), 1185-1209.

Albino, V. and Berardi U., 2012. Green Buildings and Organizational Changes in Italian Case Studies. Business Strategy and the Environment 21(6): 387-400.

Allen, D. W. and Lueck D., 2000. A Transaction Cost Primer on Farm Organization. Canadian Journal of Agricultural Economics, 48(4), 643-652.

Anderson, E. and Schmittlein, D. C. , 1984. Integration of the sale force. Rand Journal of Economics, 15(3), 385-385.

Arena, R., Festre, A., Lazaric, N., 2012. Handbook of knowledge economics. Edward Elgar.

Arora A., Andrea F., Gambardella A., 2004. Markets for technology: the economics of innovation and corporate strategy, MIT Press.

Arrow, K. J., 1971. The economic implications of learning by doing. Readings in the Theory of Growth Springer, 131-149.

Aydogan, N. and Lyon, T.P., 2004. Spatial proximity and complementarities in the trading of tacit knowledge. International Journal of Industrial Organization, 22(8-9), pp.1115-1135.

Baker, S. E., and Edwards, R. (Eds.), 2012. How many qualitative interviews is enough? UK: NCRM Methods Review Paper. http://eprints.ncrm.ac.uk/2273/4/how_many_interviews.pdf

Baker, G., Gibbons, R., Murphy, K., 2002. Relational contracts and the theory of the firm. The Quaterly Journal of Economics, 39-82.

Barraud-Didier, V., Henninger, M.-C., Triboulet, P., 2014. Member participation in agricultural cooperatives: an exploratory study of the French grain sector. Canadian Journal of Agricultural Economics, 62(1), 125-148.

Barzel, Y., 1982. Measurement costs and the Organization of Markets. Journal of Law and Economics, 25(1), 27-48

Bijman, J., 2008. Contract farming in developing countries: an overview. Wageningen University, Department of Business Administration

Bogetoft, P. and Olesen, H.B., 2002.Ten rules of thumb in contract design: lessons from Danish agriculture. European Review of Agricultural Economics, 29, 2,185-204.

Bradshaw, B., 2004. Plus c'est la même chose? Questioning crop diversification as a response to agricultural deregulation in Saskatchewan, Canada Journal of Rural Studies 20(1): 35-48

Brennan, G. and Tennant M., 2018. Sustainable value and trade-offs: Exploring situational logics and power relations in a UK brewery's malt supply network business model. Business Strategy and the Environment, 27(5): 621-630.

Brousseau, E. and Glachant, J.M., 2002. The economics of contracts and the renewal of economics. In: Brousseau, E. and Glachant, J.M., 2002. The Economics of Contract, Cambridge University Press, Cambridge, 3-30.

Caron, P., Biénabe, E., Hainzelin, E., 2014. Making transition towards ecological intensification of agriculture a reality : the gaps in and the role of scientific knowledge. Current Opinion in Environmental Sustainability, 8,44-52.

Carballo-Penela A., Mateo-Mantecón I., Alvarez S., Castromán-Diz J.L, 2018. The Role of Green Collaborative Strategies in Improving Environmental Sustainability in Supply Chains: Insights from a Case Study. Business Strategy and the Environment, vol. 27 , issue $6,728-741$ 
Cohen, W.M. and Levinthal, D. A., 1990. Absorptive Capacity: A New Perspective on Learning and Innovation. Administrative Science Quarterly, 35(1): 128.

Cowan, R. and Gunby, P., 1996. Sprayed to Death: Path Dependence, Lock-in and Pest Control Strategies.The Economic Journal , 106(436): 521-542.

Cowan, R., David, P.A., Foray, D., 2000. The explicit economics of knowledge codification and tacitness. Industrial and Corporate Change 9(2), 211-253.

Darnhofer, I., Bellon, S., Dedieu, B., Milestad, R., 2010. Adaptiveness to enhance the sustainability of farming systems. A review. Agronomy for Sustainable Development, 30, 545-555

Dequiedt, B. and Moran D., 2015. The cost of emission mitigation by legume crops in French agriculture. Ecological Economics, 110, 51-60.

Delmas, M. and Toffel. M.W., 2008. Organizational responses to environmental demands: Opening the black box, Strategic Management Journal 29(10), 1027-55.

Djanibekov, U., Van Assche, K., Boezeman, D., Djanibekov, N., 2013. Understanding contracts in evolving agro-economies: Fermers, dekhqans and networks in Khorezm, Uzbekistan. Journal of Rural Studies 32: 137-147.

Dubois P. and Vukina T., 2009. Optimal incentives under moral hazard and heterogeneous agents: evidence from production contracts data. International Journal of Industrial Organization 27(4), 489-500.

Duschek, S., 2004. Inter-firm resources and sustained competitive advantage. Management revue, 53-73.

Dyer, J.H. and Singh, H., 1998. The relational view: Cooperative strategy and sources of inter-organizational competitive advantage. Academy of management review, 23(4), pp.660-679.

Eaton, C. and Shepherd, A., 2001. Contract farming: partnerships for growth. Report from Food and Agriculture Organisations of United Nations, Rome.

Elzen, B., Augustyn, A.M., Barbier, M., van Mierlo, B., (eds), 2017. AgroEcological Transitions, Changes and Breakthroughs in the Making. Wageningen University \& Research. DOI: http://dx.doi.org/10.18174/407609

European Commission, 2018, Report From The Commission To The Council And The European Parliament on the development of plant proteins in the European Union, https://ec.europa.eu/info/sites/info/files/food-farmingfisheries/plants and plant products/documents/report-plant-proteins-com2018-757-final_en.pdf $\quad[$ Accessed the 10th december 2018]

Fares, M. and Orozco, L., 2014. Tournament Mechanism in Wine-Grape Contracts: Evidence from a French Wine Cooperative, Journal of Wine Economics, Cambridge University Press, 9 (03), 320-345.

Foss, N., 2007.The emerging knowledge governance approach. Organization, 14-1, 29-52.

Gobbato, M., 2013. Long-Term Relationships, Networks and Exchange of Knowledge in Production and Distribution Contracts.in Grundmann, S., Cafaggi, F, Giuseppe, V., Eds. The Organizational Contract: from exchange to long-term network cooperation in European contract law, Aldershot, Ashgate Publishing Ltd

Gold, S., Seuring, S., Beske, P., 2010. Sustainable supply chain management and inter-organizational resources: a literature review. Corporate Social Responsibility and Environmental Management, 17(4), 230-245.

Goodhue, R.E., Mohapatra, S., Rausser, G.C., 2010. Interactions between incentive instruments: Contracts and quality in processing tomatoes. American Journal of Agricultural Economics, 92(5), 1283-1293.

Grant, R. M., 1996. Toward a knowledge-based theory of the firm. Strategic Management Journal 17(2):109-122.

Gramzow, A., Batt, P., Afari-Sefa, V., Petrick, M., Roothaert, R., 2018. Linking smallholder vegetable producers to markets. A comparison of a vegetable producer group and a contract-farming arrangement in the Lushoto District of Tanzania. Journal of Rural Studies, 63: 168-179.

Ingram, J., 2018. Agricultural transition: Niche and regime knowledge systems' boundary dynamics. Environmental innovation and societal transitions, 26, 117-135.

James, H., and Sykuta, M., 2006. Farmer Trust in Producer- and Investor-Owned Firms: Evidence from Missouri Corn and Soybean Producers. Agribusiness, 22(1), 135-153.

Jensen, M.B., Johnson, B., Lorenz, E., Lundvall, B.Å.,2016. Forms of knowledge and modes of innovation. The learning economy and the economics of hope, pp.155-182.

Köpke U. and Nemecek T., 2010. Ecological services of faba-bean, Field Crops Research, 115, 217-233.

Kogg, B. and Mont, O., 2012. Environmental and social responsibility in supply chains: The practice of choice and interorganizational management. Ecological Economics, 83,154-163.

Labarthe, P. and Laurent C., 2013. Privatization of agricultural extension services in the EU: Towards a lack of adequate knowledge for small-scale farms? Food Policy ,38, 240-252. 
Laffont J. and Martimort D., 2002. The Theory of Incentives: The Principal-Agent Model. Princeton University Press, 440p. Lam, A., 2005. Organizational innovation, in Fagerberg et al., The Oxford Handbook of Innovation .115-148.

Langlois, R. N. and Foss, N., 1999. Capabilities and Governance: The Rebirth of Production in the Theory of Economic Organization. Kyklos 52 (2), 201-2018.

Leone, M. I., Reichstein, T., Boccardelli, P., Magnusson, M., 2016. License to learn: an investigation into thin and thick licensing contracts. R \& D Management, 46(2).

Li, J.J., Poppo L., Zhou K.Z., 2010. Relational mechanisms, formal contracts, and local knowledge acquisition by international subsidiaries. Strategic Management Journal, 31(4), 349-370.

Magrini, M.-B., Anton M., Cholez C., Corre-Hellou G., Duc G.,Jeuffroy M-H, Meynard J-M, Pelzer E., Voisin A-S, Walrand S., 2016. Why are grain-legumes rarely present in cropping systems despite their environmental and nutritional benefits? Analyzing lock-in in the French agrifood system. Ecological Economics, 126, 152-162.

Magrini M-B., Anton M., Chardigny J-M., Duc G., Duru M., Jeuffroy M-H., Meynard J-M., Micard V., Walrand S., 2018. Pulses for sustainability: breaking agriculture and food sectors out of lock-in., Frontiers in Sustainable Food Systems, section Nutrition and Environmental Sustainability, https://doi.org/10.3389/fsufs.2018.00064

Mayer, K. J. and Argyres, N. S., 2004. Learning to Contract: Evidence from the Personal Computer Industry. Organization Science 15(4), 394-410.

Mazé, A., 2002. Retailers' branding strategies: contract design, organizational change and learning. Journal on Chain and Network Science. 2(1), 33-45.

Mazé, A. and Ménard, C., 2010. Private ordering, collective action, and the self-enforcing range of contracts. European Journal of Law and Economics, 29(1), 131-153.

Mazé, A., Ait-Aissa M., Mayer S., Verjux N., 2016. Third-Party Certifications and the Role of Auditing Policies in Sustainability. The Time and Space of Materiality Within Combined Audits, Organization \& Environment 29(3), 398-331.

Mazé, A., 2017. Standard setting activities and new institutional economics. Journal of Institutional Economics, 13(3), 599621.

Meehan, J. and Bryde D., 2011. Sustainable procurement practice. Business Strategy and the Environment 20(2): 94-10

Melander, L., 2018. Customer and Supplier Collaboration in Green Product Innovation: External and Internal Capabilities. Business Strategy and the Environment 27(6): 677-693.

Ménard, C., 2012. Hybrid Modes of Organization. Alliances, Joint Ventures, Networks, and Other 'Strange' Animals. In Gibbons, R. et Roberts J. The Handbook of Organizational Economics, Princeton University Press, 1066-1108.

Ménard, C. and Valceschini, E., 2005. New institutions for governing the agri-food industry. European Review of Agricultural Economics, 32(3), 421-440.

Meynard, J.M., Charrier, F., Le Bail, M., Magrini, M.B., Charlier, A. and Messéan, A., 2018. Socio-technical lock-in hinders crop diversification in France. Agronomy for Sustainable Development, 38(5), p.54.

Meynard, JM., Jeuffroy, MH., Le Bail, M., Lefèvre, A., Magrini, MB., Michon, C., 2017. Designing coupled innovations for the sustainability transition of agrifood systems. Agricultural Systems, 157, 330-339.

Minot, N., 2018. Contract Farming in Developing Countries: Patterns, Impact, and Policy Implications (6-3). Case Studies in Food Policy for Developing Countries: Domestic Policies for Markets, Production, and Environment, 2, p.37.

Mowery, D.C., Oxley J.E., Silverman, B.S., 1996. Strategic alliances and inter-firm knowledge transfer. Strategic Management Journal, 17, 77-91.

Nickerson, J. A. and Zenger T., 2004. A knowledge-based theory of the firm: the problem solving perspective. Organization Science, 15, 617-622.

Nguyen, A.T., Dzator, J., Nadolny, A., 2015. Does contract farming improve productivity and income of farmers?: A review of theory and evidence. The Journal of Developing Areas, 49(6), pp.531-538.

North, D., 2005. Understanding the process of economic change. Princeton University Press.

Mawois M., Nguyen G., Casagrande M., 2017. Freins et leviers à l'insertion des légumineuses : étude comparative de trois territoires contrastés (Bourgogne, Midi-Pyrénées, Pays de la Loire), Innovations Agronomiques, 60, 91-105.

Minot, N., 2018. Contract Farming in Developing Countries: Patterns, Impact, and Policy Implications (6-3). Case Studies in Food Policy for Developing Countries: Domestic Policies for Markets, Production, and Environment, 2, p.37.

Nooteboom, B., 2004. Learning and governance in inter-firm relations. Revue d'économie politique, 114(1), 55-76. 
Oelze, N., Hoejmose, S., Habisch, A., Millington, A., 2016. Sustainable Development in Supply Chain Management: The Role of Organizational Learning for Policy Implementation. Business Strategy and the Environment 25(4): 241-260.

Penrose, E. T., 1959. The Theory of the Growth of the Firm. Oxford: Basil Blackwell,1-22.

Pogutz, S. and Winn M. I., 2016. Cultivating Ecological Knowledge for Corporate Sustainability: Barilla's Innovative Approach to Sustainable Farming. Business Strategy and the Environment 25(6): 435-448.

Powell W.and Grodal S., 2005. Networks of innovators. In Fagerberg et al., The oxford handbook of innovation, 56-86.

Prowse, M., 2012. Contract farming in developing countries: a review: Institute of development policy and management, university of Antwerp.

Raynaud E., Sauvée L., Valceschini E., 2009. Aligning branding strategies and governance of vertical transactions in agri-food chains. Industrial and Corporate Change, 18(5), 835-868.

Reuer, J. J. and Ariño A., 2007. Strategic alliance contracts: dimensions and determinants of contractual complexity. Strategic Management Journal, 28(3), 313-330.

Ricome A., Chaib K., Ridier A., 2016. The role of marketing contracts in the adoption of low-input practices in the presence of income supports . Journal of Agricultural and Resource Economics, 41 (3), 347-371.

Saldana, J., 2015. The coding manual for qualitative researchers. Third edition, Sage Publication.

Sarkis J., Zhu, Q., Lai, K., 2011. An organizational theoretic review of green supply chain management literature, International Journal of Production Economics, 130, 1-15.

Sharfman, M.P., Shaft, T.M., Anex, R.P. (2009). The road to cooperative supply-chain environmental management: Trust and uncertainty among pro-active firms. Business Strategy \& the Environment, 18(1), 1-13.

Sykuta, M. E. and James H. S. (2004). Organizational economics research in the U.S. agricultural sector and the contracting and organizations research institute. American Journal of Agricultural Economics, 86(3), 756-76.

Šumane, S., et al. (2018). Local and farmers' knowledge matters! How integrating informal and formal knowledge enhances sustainable and resilient agriculture. Journal of Rural Studies, 59,232-241.

Van Hoof, Bart, and Thomas P. Lyon. (2013). Cleaner production in small firms taking part in Mexico's Sustainable Supplier Program. Journal of Cleaner Production, 41, 270-282.

Vanloqueren, G.and Baret, P.V., 2009. How agricultural research systems shape a technological regime that develops genetic engineering but locks out agroecological innovations. Research Policy 38 (6), 971-983.

Wang, H. H., Wang, Y., Delgado, M. S. (2014). The Transition to Modern Agriculture: Contract Farming in Developing Economies." American Journal of Agricultural Economics, 96(5), 1257-1271.

Watanabe, K., et al. (2017). Pingado Dilemma": Is formal contract sweet enough? Journal of Rural Studies 54: 126-137.

Weleschuk, I.T. and Kerr, W.A., 1995. The sharing of risks and returns in prairie special crops: a transaction cost approach. Canadian Journal of Agricultural Economics/Revue canadienne d'agroeconomie, 43(2), pp.237-258.

Williamson, O.E. (1989). Transaction cost economics, in Schmalensee R., Willig R. Handbook of Industrial Organization, New York, North-Holland, 135-182.

Williamson, O. E. (1991). Comparative economic organization: The analysis of discrete structural alternatives, Administrative Science Quarterly 36, 269-296.

Wilson, W. W. and Dahl B. (2014). Contracting for Canola in the Great Plains States. Canadian Journal of Agricultural Economics, 62(1), 89-106.

Yin, R.K. (2014). Case study research: design and methods. SAGE Publications.

Zimmer, S., Liebe, U., Didier, J-P., Heß, J. (2016). Luxembourgish farmers' lack of information about grain legume cultivation. Agronomy for Sustainable Development, 36(2)

\section{Tables}


Table 1: Combination of bilateral production contract and collective governance in the

\section{GTO association}

\begin{tabular}{|c|c|c|}
\hline & $\begin{array}{c}\text { Production contract } \\
\text { Set up before planting, for one year }\end{array}$ & $\begin{array}{l}\text { Collective governance } \\
3 \text { to } 4 \text { meetings per year }\end{array}$ \\
\hline Quantity & $\begin{array}{l}\text { Commitment before planting } \\
\text { (in volume for the SO contracting with } \\
\text { the industry) }\end{array}$ & $\begin{array}{l}\text { Allocation of the volume between } \\
\text { the suppliers through negotiation } \\
\text { and adaptation during the } \\
\text { production campaign }\end{array}$ \\
\hline Price fixation & $\begin{array}{l}\text { Minimum guaranteed price before } \\
\text { planting }\end{array}$ & $\begin{array}{c}\text { Negotiation of the final price } \\
\text { before harvest }\end{array}$ \\
\hline $\begin{array}{c}\text { Product } \\
\text { specifications }\end{array}$ & $\begin{array}{l}\text { Wholesome, unadulterated and } \\
\text { merchantable quality }\end{array}$ & $\begin{array}{l}\text { Will become more precise } \\
\text { depending on the outcome of } \\
\text { buyer's R\&D }\end{array}$ \\
\hline $\begin{array}{l}\text { Production } \\
\text { requirements }\end{array}$ & $\begin{array}{c}\text { Required list of seed varieties according } \\
\text { to qualitative performance } \\
\text { characteristics }\end{array}$ & $\begin{array}{c}\text { Discussion of varieties' } \\
\text { performance and reviewing of the } \\
\text { list each campaign }\end{array}$ \\
\hline
\end{tabular}

Table 2: Links between contractual dimensions and knowledge

\begin{tabular}{l|l}
\hline Mechanisms & Knowledge type \\
\hline Formal specifications in the contract & Codified \\
\hline Crop management form & Codified \\
Analysis of all forms and restitution & Both tacit and codified \\
\hline Face-to-face interactions & \\
- during contract negotiations & \\
- during annual fields visits with the growers & Both tacit and codified \\
\hline Specific investment made by the SO in training program for their farming \\
advisors
\end{tabular}


Specific investment made by the SO in experimentation program

\section{Figures}

Figure 1: Toward a new analytical framework

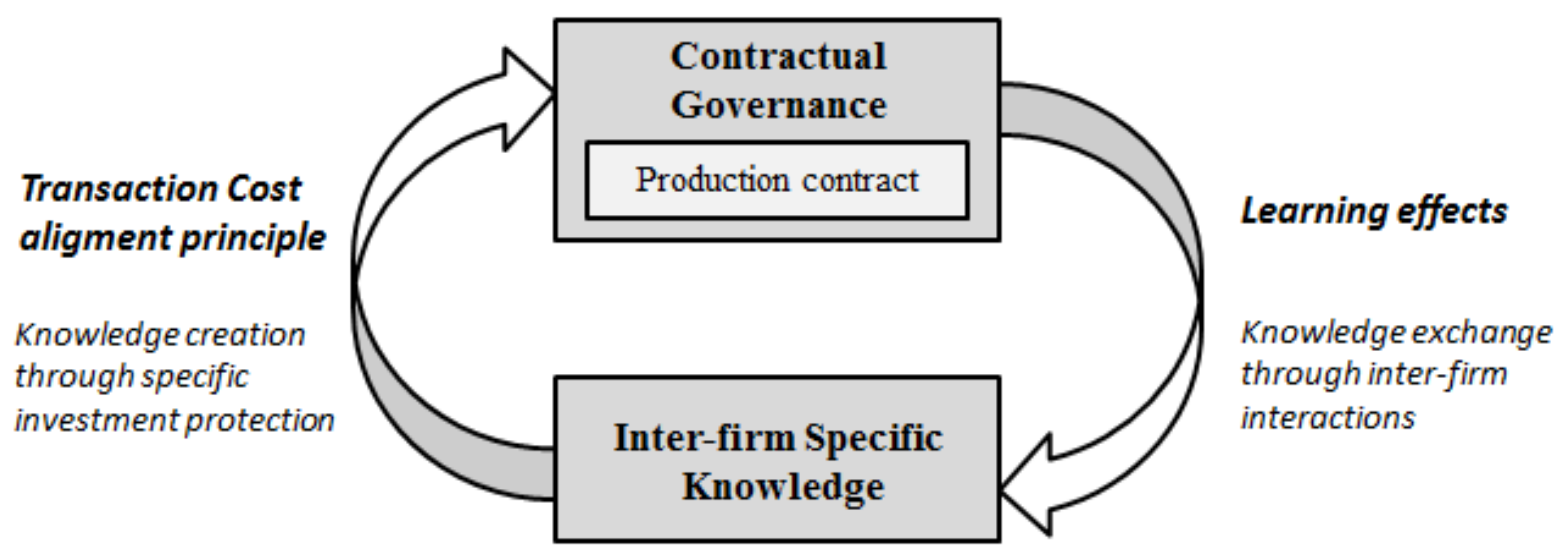

Figure 2a: The collective governance of bilateral production contracts through the Graines

Tradition Ouest (GTO) Association

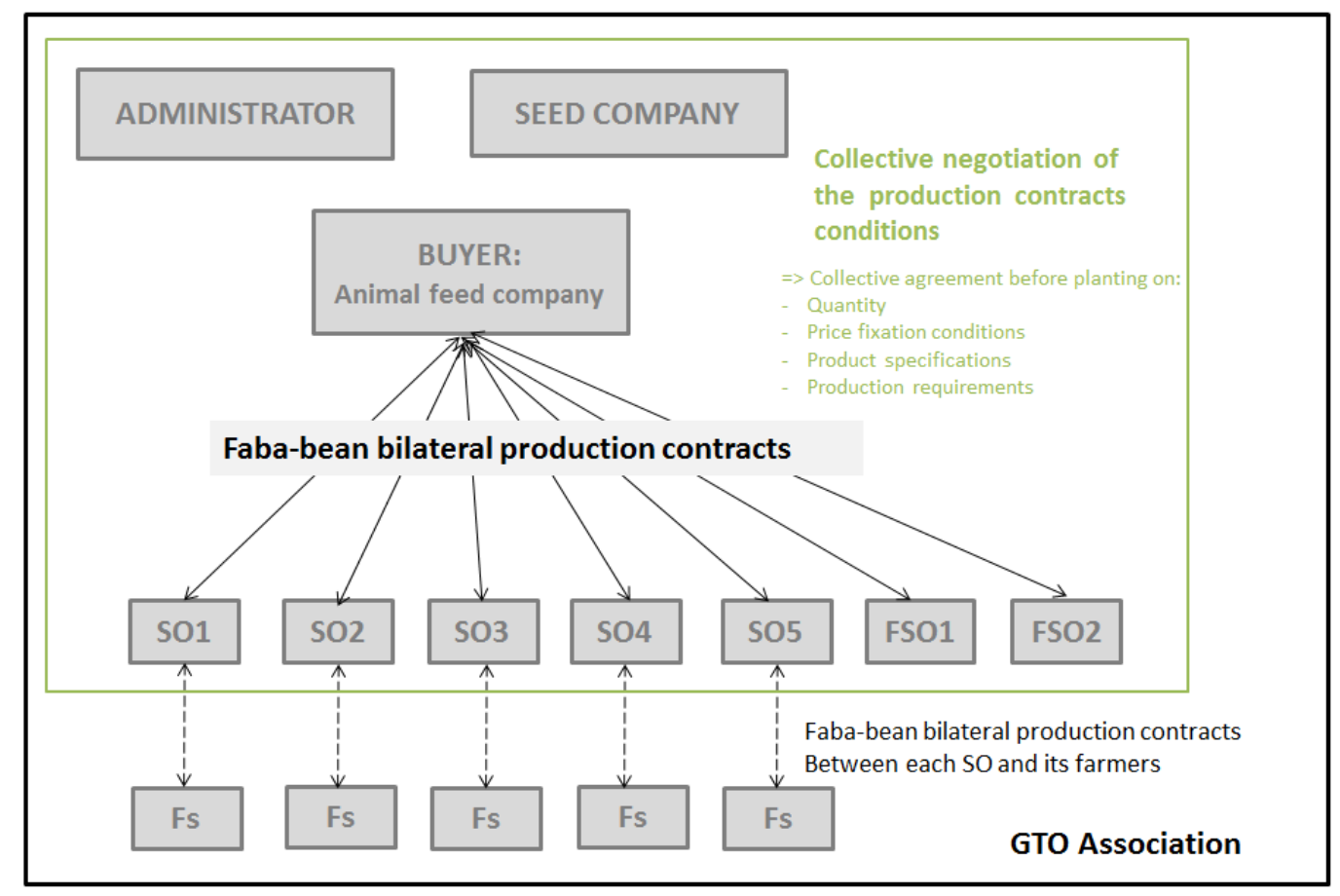


Figure 2b: The commercial links between the GTO members

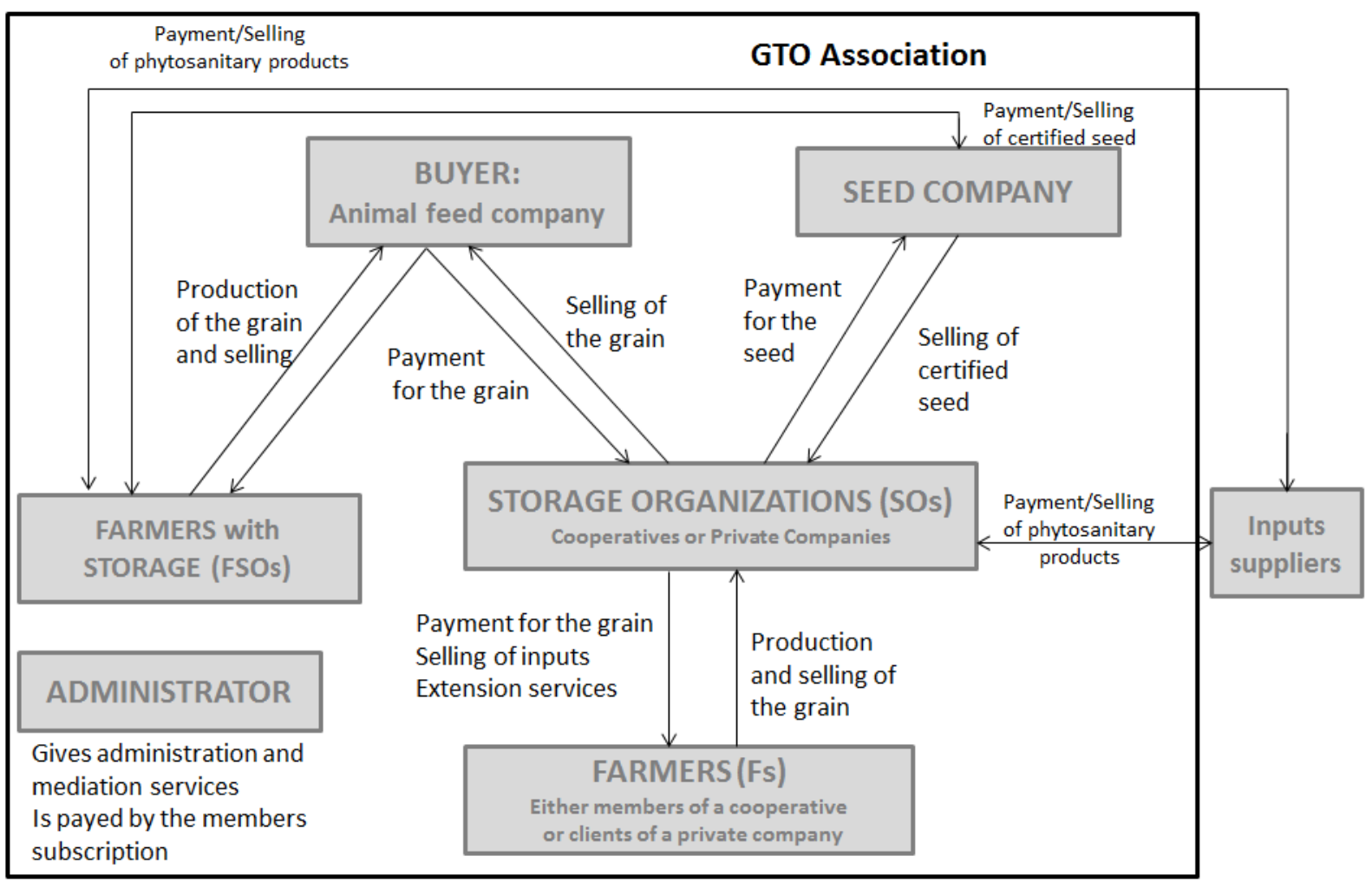

\section{Appendix A: Characteristics the GTO Association members}

\begin{tabular}{|c|c|c|c|c|c|c|}
\hline GTO members & Status & $\begin{array}{l}\mathrm{CA} \\
\text { (M€) }\end{array}$ & $\begin{array}{l}\text { Volume of } \\
\text { total grain } \\
\text { processed } \\
\text { or } \\
\text { collected } \\
\text { (T) }\end{array}$ & $\begin{array}{l}\text { Fababean } \\
\% \text { of the } \\
\text { collect }\end{array}$ & $\begin{array}{l}\text { Planted } \\
\text { surface of } \\
\text { fababean } \\
\text { under } \\
\text { Production } \\
\text { contracts } \\
\text { (ha) }\end{array}$ & $\begin{array}{l}\text { Number of } \\
\text { farmers } \\
\text { under } \\
\text { Production } \\
\text { contracts }\end{array}$ \\
\hline $\begin{array}{l}\text { Industry } \\
\text { (animal feed } \\
\text { company) }\end{array}$ & $\begin{array}{l}\text { private owned } \\
\text { firm }\end{array}$ & 72 & 200000 & 4 & - & - \\
\hline $\begin{array}{l}\text { Storage } \\
\text { Organisation } 1\end{array}$ & $\begin{array}{l}\text { private owned } \\
\text { firm }\end{array}$ & na & 250000 & 0,29 & 150 & 15 \\
\hline $\begin{array}{l}\text { Storage } \\
\text { Organisation } 2\end{array}$ & cooperative & 2000 & 900000 & 0,1 & 155 & 50 \\
\hline $\begin{array}{l}\text { Storage } \\
\text { Organisation } 3\end{array}$ & cooperative & 114 & 125000 & 0,01 & 15 & 2 \\
\hline $\begin{array}{l}\text { Storage } \\
\text { Organisation } 4\end{array}$ & cooperative & 4800 & 1740000 & 0,18 & 210 & 22 \\
\hline $\begin{array}{l}\text { Storage } \\
\text { Organisation } 5\end{array}$ & cooperative & 320 & 250000 & 0,04 & 20 & 3 \\
\hline $\begin{array}{l}\text { Farmer } \\
\text { Storage } \\
\text { Organisation } 1\end{array}$ & $\begin{array}{l}\text { private owned } \\
\text { firm }\end{array}$ & na & na & na & 7 & 1 \\
\hline
\end{tabular}




\begin{tabular}{llllllc}
\hline $\begin{array}{l}\text { Farmer } \\
\begin{array}{l}\text { Storage } \\
\text { Organisation 2 }\end{array}\end{array}$ & $\begin{array}{l}\text { private owned } \\
\text { firm }\end{array}$ & na & na & na & 18 & 1 \\
\hline $\begin{array}{l}\text { Seed } \\
\text { Company }\end{array}$ & $\begin{array}{l}\text { private owned } \\
\text { firm }\end{array}$ & 12 & none & none & none & none \\
\hline $\begin{array}{l}\text { Administrator } \\
\begin{array}{l}\text { Extension } \\
\text { service) }\end{array}\end{array}$ & public service & nr & none & none & none & none \\
\hline
\end{tabular}

The geographical area of the GTO association In France

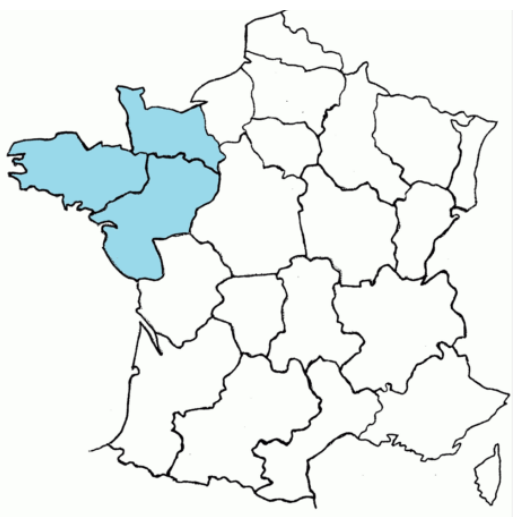

Appendix B. Main Items in the Interviews and position of respondents Main items in the interviews:

Governance of production and sales of faba beans within the GTO

The GTO association: goals, organisation, operations, etc.

The production contract: duration, commitments, end product specifications, process specifications

Process for creating the contract, negotiations, modifying the contract, monitoring the contract

The specialised knowledge called upon in these various stages

Growing faba bean within the GTO

Historical yields and production development issues

Technical aspects:

Factors that prevent increasing production

Investments made and the kinds of knowledge used for production

Short-term investment and knowledge needs

Characteristics of faba bean sales within the GTO

Kinds of uncertainty involved in the transaction and the specificity of assets required to ensure the transaction 
Position of respondents:

\begin{tabular}{|c|c|c|c|}
\hline GTO members & $\begin{array}{l}\text { Code } \\
\text { for } \\
\text { quote }\end{array}$ & $\begin{array}{l}\text { Number of } \\
\text { respondants }\end{array}$ & Position of respondants \\
\hline $\begin{array}{l}\text { Industry } \\
\text { (Animal feed } \\
\text { company) }\end{array}$ & 1 & 4 & $\begin{array}{l}\text { Raw materials buyer } \\
\text { Head of R\&D } \\
\text { R\&D engineer in animal nutrition } \\
\text { Head of marketing technical support }\end{array}$ \\
\hline $\begin{array}{l}\text { Storage } \\
\text { Organisation } 1\end{array}$ & SO1 & 1 & Director \\
\hline $\begin{array}{l}\text { Storage } \\
\text { Organisation } 2\end{array}$ & SO2 & 1 & Head of the cereals department \\
\hline $\begin{array}{l}\text { Storage } \\
\text { Organisation } 3\end{array}$ & $\mathrm{SO} 3$ & 1 & Head of plant production advising department \\
\hline $\begin{array}{l}\text { Storage } \\
\text { Organisation } 4\end{array}$ & SO4 & 1 & Head of field crops sale department \\
\hline $\begin{array}{l}\text { Storage } \\
\text { Organisation } 5\end{array}$ & SO5 & 1 & Head of plant production development \\
\hline $\begin{array}{l}\text { Farmer } \\
\text { Storage } \\
\text { Organization } 1 \\
\end{array}$ & F1 & 1 & Head of the farm \\
\hline $\begin{array}{l}\text { Farmer } \\
\text { Storage } \\
\text { Organization } 2 \\
\end{array}$ & F2 & 1 & Head of the farm \\
\hline $\begin{array}{l}\text { Seed } \\
\text { Company }\end{array}$ & SC & 2 & $\begin{array}{l}\text { Sales director } \\
\text { Grain-legume seed breeder }\end{array}$ \\
\hline Administrator & ES & 1 & Commercial advisor also administrator of GTO \\
\hline
\end{tabular}

